\title{
A non-catecholamine-producing sympathetic paraganglioma of the spermatic cord: the importance of performing candidate gene mutation analysis
}

\author{
Despoina Alataki • A. Triantafyllidis • José Gaal • \\ C. Rodiou • J. Vouros • A. Papathanasiou • \\ A. Papanicolaou • V. Rombis • Ronald R. de Krijger
}

Received: 7 May 2010 /Revised: 13 August 2010 /Accepted: 18 August 2010 /Published online: 15 September 2010

(C) The Author(s) 2010. This article is published with open access at Springerlink.com

\begin{abstract}
Background Catecholamine-producing tumours are called pheochromocytomas when they are located in the adrenal gland and sympathetic paragangliomas when they are located elsewhere in the abdomen. Rarely these tumours do not produce catecholamines and even more rarely they arise in the spermatic cord. Over the past decade, systematic mutation analysis of apparently sporadic cases of pheochromocytomas and paragangliomas has elucidated the frequent presence of germ line mutations in one of five candidate genes, including RET, VHL, SDHB, SDHC, and SDHD.

Clinical history and methods We describe a 45-year-old man with a non catecholamine-producing paraganglioma of the spermatic cord. We performed SDHB immunohistochemistry and performed mutation analysis of the $S D H B$, $S D H C$, and $S D H D$ genes.

Results There was no staining of tumour cells with SDHB immunohistochemistry, indicative of an $S D H$ mutation.
\end{abstract}

Precis Candidate gene mutation analysis on a paraganglioma of the spermatic cord

D. Alataki $\cdot$ A. Papanicolaou

Department of Pathology,

Hippokration General Hospital of Thessaloniki,

Thessaloniki, Greece

A. Triantafyllidis $\cdot$ C. Rodiou $\cdot$ J. Vouros $\cdot$ A. Papathanasiou $\cdot$

V. Rombis

Department of Urology,

Hippokration General Hospital of Thessaloniki,

Thessaloniki, Greece

J. Gaal $\cdot$ R. R. de Krijger $(\bowtie)$

Department of Pathology, Josephine Nefkens Institute,

Erasmus MC-University Medical Center Rotterdam,

P.O. Box 2040, 3000 CA Rotterdam, The Netherlands

e-mail: r.dekrijger@erasmusmc.nl
Mutation analysis demonstrated a germ line SDHD mutation (p.Val147Met).

Conclusions Systematic mutation analysis is required in paraganglioma patients for the detection of germ line mutations. This should be preceded by SDHB immunohistochemistry to limit the number of genes to be tested.

Keywords Sympathetic paraganglioma $\cdot$ Spermatic cord . SDHD $\cdot$ Immunohistochemistry

\section{Introduction}

Extra-adrenal tumours originating from chromaffin cells are called sympathetic paragangliomas and arise from paraganglia that are distributed along the pre- and paravertebral sympathetic chains and the sympathetic nerve fibres, which innervate the pelvic and retroperitoneal organs. In contrast, tumours originating from the adrenal medulla are called pheochromocytomas [1]. Between $25 \%$ and $79 \%$ of sympathetic paragangliomas and about $90 \%$ of pheochromocytomas are associated with clinical signs of excess catecholamine secretion, while the remaining cases represent clinically non-functional tumours [2]. Most of these tumours produce but do not secrete catecholamines and may therefore evade detection for many years.

The majority of sympathetic paragangliomas occur in various abdominal sites, mostly in a paravertebral location, or in the organ of Zuckerkandl, a sympathetic paraganglion that plays an important role early in life. More rarely, sympathetic paragangliomas have been described in the bladder wall, which may elicit micturition-related complaints of excess catecholamine secretion $[3,4]$. An even less frequent location is in the spermatic cord, where until 
now eight cases had been described in the international literature [5-12]; however, none of these have been investigated for mutations in sympathetic paragangliomarelated genes. An overview of the clinical data of these previous eight patients is presented in Table 1 .

Between $12 \%$ and $24 \%$ of apparently sporadic paragangliomas have been shown over the past decade to have a hereditary basis, involving mutations in one of five different genes: the REarranged during Transfection (RET) proto-oncogene, the von Hippel-Lindau (VHL) gene, and the succinate dehydrogenase subunits B $(S D H B), \mathrm{C}$ $(S D H C)$, and D (SDHD) genes [13], [14].

In the present study, we report the first case of a spermatic cord sympathetic paraganglioma in which the tumour tissue was investigated by SDHB immunohistochemistry. This was shown to be a useful tool in diagnosing paraganglioma patients with $S D H x$ mutations; negative immunostaining was seen in paragangliomas with $S D H x$ mutations, whereas paragangliomas without mutations are positive with SDHB immunohistochemistry [15]. In this spermatic cord sympathetic paraganglioma, the negative immunostaining gave an important clue for the presence of an $S D H x$ mutation, which was subsequently shown to be a previously unknown germ line $S D H D$ mutation.

\section{Clinical history}

A 45-year-old man presented with a painless lump in his left hemiscrotum of months' duration. In his past medical history, an episode of acute left epididymitis, which subsided with antibiotics, was recorded 20 years earlier. On physical examination, a palpable, painless, firm mass was revealed in the upper pole of this left testicle. With a provisional diagnosis of a testicular neoplasm, a left inguinal orchiectomy was recommended and subsequently performed. His blood pressure was stable during and after surgery. The orchiectomy specimen displayed a tumour mass confined to the spermatic cord measuring $4.8 \times 3.3 \times$ $2.5 \mathrm{~cm}$, weighing $71 \mathrm{~g}$, surrounded by a capsule. The cut surface showed homogeneously reddish-white tumour tissue with an elastic consistency, while both the testis and epididymis were of normal colour, shape, and consistency (Fig. 1a).

Microscopically, there was a solid-looking tumour, with well-defined nests or trabeculae of tumour cells, separated by highly vascularized septa, focally thickened and hyalinized (Fig. 1b). Immunohistochemically, the tumour cells displayed strong and diffuse reactivity for vimentin, chromogranin A (Fig. 1c), synaptophysin, and neuron-specific enolase. Moreover, sustentacular cells were immunoreactive for S-100 protein. Taken together, a diagnosis of an abdominal, presumably sympathetic, paraganglioma was proffered. Following this histological diagnosis, the urologists performed an additional 24-h urinary analysis of catecholamines and their metabolites, which was shown to be normal. Three years after surgery, the patient is healthy, free of disease, and without tumours at other anatomic sites. There were no other family members known to the patient that had one or more pheochromocytomas or paragangliomas.

\section{Material and methods}

DNA was isolated from formalin fixed paraffin-embedded (FFPE) material. A region of at least $80 \%$ tumour cells was micro-dissected, and DNA was isolated using the Puregene DNA isolation kit (Gentra, Minneapolis, USA) according to manufacturer's protocol. An SDHB immunohistochemistry was performed using the rabbit polyclonal antibody HPA002868 (Sigma-Aldrich Corp, St. Louis, MO; 1:500) according to the method described by van Nederveen et al. [15]. Subsequently, mutation analysis was performed by direct sequencing of tumour tissue.

\section{Results}

The SDHB immunohistochemistry did not show any reactivity of the neoplastic cells (Fig. 1d). The mutation

Table 1 Clinical data of the previous eight patients with spermatic cord PGL

\begin{tabular}{llllll}
\hline & Age & Symptoms & Hormonally active & Additional tumours & Reference \\
\hline 1 & 37 & Painless mass right scrotal sac for 10 years & No & No & Eusebi et al. [5] \\
2 & 52 & $\begin{array}{l}\text { Painless mass left scrotal sac for } \\
\text { 10 years/elevated blood pressure at operation }\end{array}$ & Yes & No & Soejima et al. [6] \\
3 & 18 & Painless mass in right scrotal sac for 2 years & No & No & Bacchi at al. [7] \\
4 & 37 & Painful mass in right scrotal sac & No & No & Mashat et al. [8] \\
5 & 40 & Painless mass in left scrotal sac & No & No & Attaran et al. [9] \\
6 & 52 & Lump within the right spermatic cord & No & No & Young et al. [10] \\
7 & 55 & Painless left scrotal mass & Yes & Bilateral carotid body paragangliomas & Abe et al. [11] \\
8 & 69 & Weight loss, malaise, and mass in right testicle & No & No bilateral pheochromocytomas & Garaffa et al. [12] \\
\hline
\end{tabular}


Fig. 1 a Gross aspect of spermatic cord paraganglioma. b Typical histology of the tumour showing large polygonal cells with ample amphophilic cytoplasm and moderate nuclear pleomorphism. c Chromogranin A immunohistochemistry showing positive staining in the tumour cells. d SDHB immunohistochemistry showing negative staining in tumour cells, while endothelial cells are immunoreactive. e Mutation analysis showing a p.Val147Met mutation in the tumour DNA compared with normal reference DNA
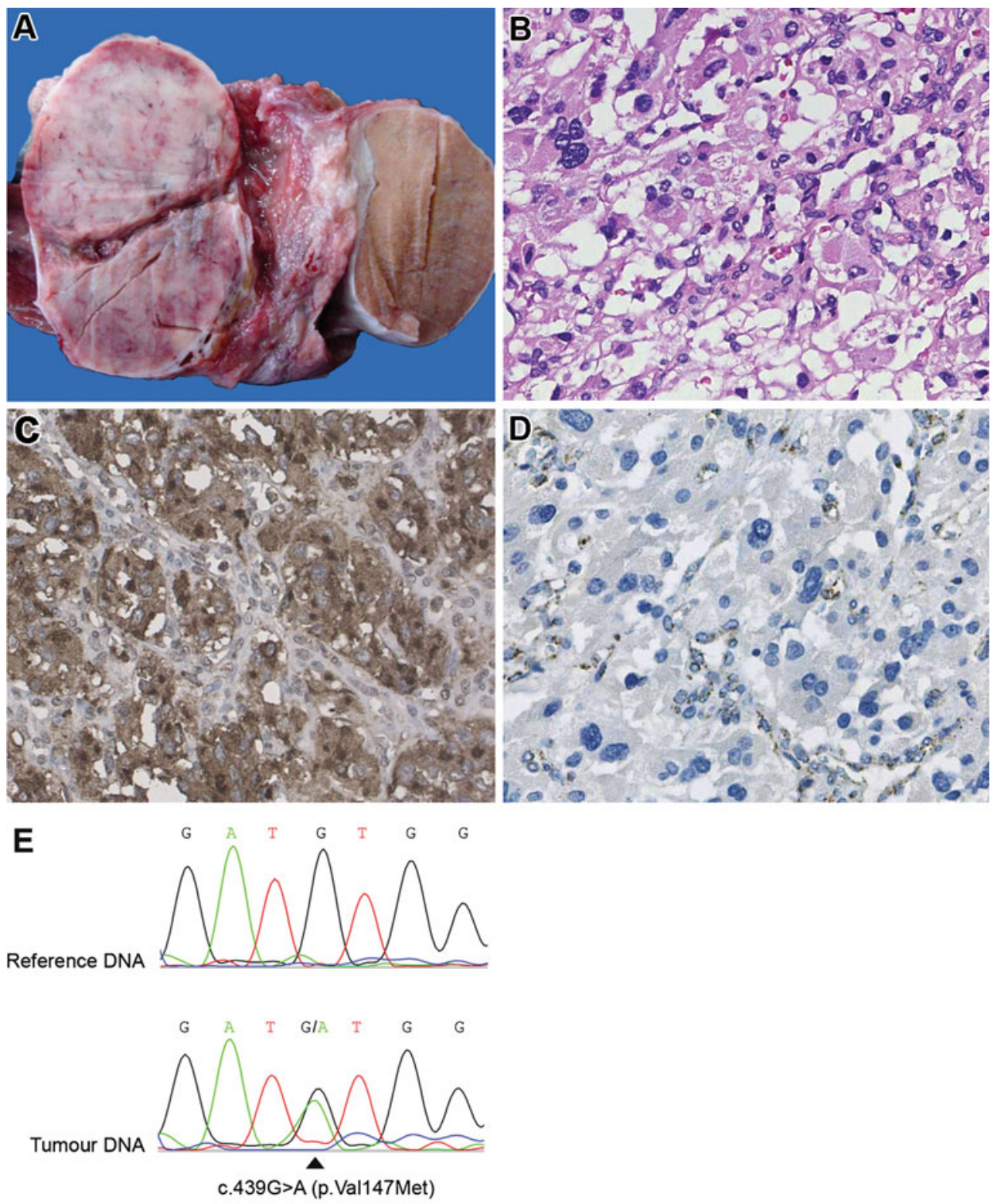

analysis that was performed by direct sequencing, on tumour tissue of this patient, showed an SDHD mutation in exon 4 (c.439 G $\rightarrow$ T, p.Val147Met) (Fig. 1e).

\section{Discussion}

In the present case report, we have described, for the first time in an individual case the use of SDHB immunohistochemistry for the guidance of subsequent DNA mutation analysis. Because of negative immunostaining, an $S D H x$ mutation was predicted and eventually shown to be a $\mathrm{p}$. Val147Met SDHD mutation.

This patient represents the ninth patient in the English literature with a spermatic cord paraganglioma, which was detected by its local mass effect, as it did not appear to produce catecholamines. The latter has not been formally proven, as no biochemical analyses had been carried out prior to surgery; however, the patient did not report any complaints that could be related to high blood pressure and/or catecholamine excess. The unusual location for a paraganglioma in the spermatic cord has been attributed to migration of neural crest progenitor cells, which are known to be present in the paraganglia throughout the abdomen, as is reflected by the various locations of abdominal sympathetic paraganglioma [16]. It is entirely conceivable that these progenitor cells migrate along with the developing male gonad and give rise to paragangliomas at low frequency.

Thus far, these paragangliomas have been described in middle-aged men, none of whom has had genetic testing, although one patient clearly had evidence of multiple tumours, for which we would strongly recommend systematic candi- 
date gene mutation analysis [11]. Until about 10 years ago, pheochromocytomas and paragangliomas were known to occur in the context of various tumour syndromes, including multiple endocrine neoplasia type 2 (MEN 2), VHL disease, and NF1. Since the beginning of this decade, four additional genes (SDHB, SDHC, SDHD, and SDHAF2) have been added, causing the pheochromocytoma-paraganglioma syndrome, characterized by the occurrence of multiple pheochromocytoma and/or paraganglioma in the same patient and his or her family members. Whereas originally the frequency of germ line mutations in pheochromocytomas and paragangliomas was estimated at $10 \%$, based upon patients from clearly recognizable familial tumour syndromes, systematic analysis of all genes (with the exception of $N F 1$ ) has shown that an additional $15-25 \%$ of pheochromocytoma and paraganglioma patients are carriers of germ line mutations in each of these genes $[13,14]$. Although somatic mutations in some of these genes have been described, they are quantitatively insignificant [4].

The finding of this mutation has important implications for further patient management, as it is known that patients with SDHD germ line mutations are at increased risk to develop further paragangliomas, either abdominal or head and neck, or even pheochromocytomas. In addition, other family members may also be affected, so they should be screened too.

Taken together, we show here that the spermatic cord can be a rare location for the occurrence of paragangliomas in male patients and that a stepwise immunohistochemical and genetic approach can be employed for the diagnosis of inherited paraganglioma, even in the absence of a positive family history.

Acknowledgements We are grateful to Frank van der Panne for the help in preparing the figures.

Conflict of interest statement We declare that we have no conflict of interest.

Funding José Gaal is supported by a grant of Erasmus MC.

Open Access This article is distributed under the terms of the Creative Commons Attribution Noncommercial License which permits any noncommercial use, distribution, and reproduction in any medium, provided the original author(s) and source are credited.

\section{References}

1. Timmers HJ, Gimenez-Roqueplo AP, Mannelli M, Pacak K (2009) Clinical aspects of SDHx-related pheochromocytoma and paraganglioma. Endocr Relat Cancer 16(2):391-400
2. Erickson D, Kudva YC, Ebersold MJ, Thompson GB, Grant CS, van Heerden JA, Young WF Jr (2001) Benign paragangliomas: clinical presentation and treatment outcomes in 236 patients. $\mathrm{J}$ Clin Endocrinol Metab 86(11):5210-5216

3. Im SH, Kim NH (2008) Thunderclap headache after micturition in bladder pheochromocytoma. Headache 48(6):965-967

4. van Nederveen FH, Korpershoek E, Lenders JW, de Krijger RR, Dinjens WN (2007) Somatic SDHB mutation in an extraadrenal pheochromocytoma. N Engl J Med 357(3):306-308

5. Eusebi V, Massarelli G (1971) Phaeochromocytoma of the spermatic cord: report of a case. J Pathol 105(4):283-284

6. Soejima H, Ogawa O, Nomura Y, Ogata J (1977) Pheochromocytoma of the spermatic cord: a case report. J Urol 118(3):495496

7. Bacchi CE, Schmidt RA, Brandao M, Scapulatempo R, Costa JC, Schmitt FC (1990) Paragangliomaof the spermatic cord. Report of a case with immunohistochemical and ultrastructural studies. Arch Pathol Lab Med 114(8):899-901

8. Mashat F, Meccawi A, Garg S, Christian E (1993) Paraganglioma of the spermatic cord. Ann Saudi Med 13(2):208-210

9. Attaran SY, Shakeri S, Sobhani AR (1996) Paraganglioma of the spermatic cord: report of a case. J Urol 155(2):651

10. Young IE, Nawroz IM, Aitken RJ (1999) Phaeochromocytoma of the spermatic cord. J Clin Pathol 52(4):305-306

11. Abe T, Matsuda H, Shindo J, Nonomura K, Koyanagi T (2000) Ectopicpheochromocytoma arising in the spermatic cord 5 years after removal of bilateral carotid body tumors and adrenal pheochromocytomas. Int J Urol 7(3):110-111

12. Garaffa G, Muneer A, Freeman A, Abdel Raheem AM, Ralph DJ, Minhas S, Rees RW (2008) Paraganglioma of the spermatic cord: case report and review of the literature. Sci World J 8:1256-1258

13. Amar L, Bertherat J, Baudin E, Ajzenberg C, Bressac-de Paillerets B, Chabre O, Chamontin B, Delemer B, Giraud S, Murat A, Niccoli-Sire P, Richard S, Rohmer V, Sadoul JL, Strompf L, Schlumberger $\mathrm{M}$, Bertagna $\mathrm{X}$, Plouin $\mathrm{PF}$, Jeunemaitre $\mathrm{X}$, Gimenez-Roqueplo AP (2005) Genetic testing in pheochromocytoma or functionalparaganglioma. J Clin Oncol 23(34):8812-8818

14. Neumann HP, Bausch B, McWhinney SR, Bender BU, Gimm O, Franke G, Schipper J, Klisch J, Altehoefer C, Zerres K, Januszewicz A, Eng C, Smith WM, Munk R, Manz T, Glaesker S, Apel TW, Treier M, Reineke M, Walz MK, Hoang-Vu C, Brauckhoff M, Klein-Franke A, Klose P, Schmidt H, MaierWoelfle M, Peczkowska M, Szmigielski C (2002) Germ-line mutations in nonsyndromic pheochromocytoma. N Engl J Med 346(19):1459-1466

15. van Nederveen FH, Gaal J, Favier J, Korpershoek E, Oldenburg RA, de Bruyn EM, Sleddens HF, Derkx P, Riviere J, Dannenberg H, Petri BJ, Komminoth P, Pacak K, Hop WC, Pollard PJ, Mannelli M, Bayley JP, Perren A, Niemann S, Verhofstad AA, de Bruine AP, Maher ER, Tissier F, Meatchi T, Badoual C, Bertherat J, Amar L, Alataki D, Van Marck E, Ferrau F, Francois J, de Herder WW, Peeters MP, van Linge A, Lenders JW, GimenezRoqueplo AP, de Krijger RR, Dinjens WN (2009) An immunohistochemical procedure to detect patients with paraganglioma and phaeochromocytoma with germline $S D H B, S D H C$, or $S D H D$ gene mutations: a retrospective and prospective analysis. Lancet Oncol 10(8):764-771

16. Jaffer S, Harpaz N (2002) Mesenteric paraganglioma: a case report and review of the literature. Arch Pathol Lab Med 126 (3):362-364 